\section{POOR-LAW MEDICAL REFORM.}

To the Editor of THE LANCET.

SIR,-I shall feel obliged by your giving insertion to the annexed correspondence, which I regret to say gives no hope of any amelioration of the condition of the Poor-law medical officers this session. $\quad 1 \mathrm{am}, \mathrm{Sir}$, yours \&c.

12, Royal-terrace, Weymouth, July 11th, 1863

RiCHARD GRIFFin.

12, Royal-terrace, Weymouth, July 8 th, 1863 .

Sir, - On the 22nd of June I had the honour to forward to you, as the Chairman of the Select Committee on Poor Relief, certain documents which I desired might be laid before the Select Committee, May I ask the favour of your informing me if they have been received?-and, also, if they have been considered?- - if not, when they are likely to be brought under the notice of the Select Committee? These documents I hold to be very important, as they not only contain a refutation of all the material points in Mr. Cane's evidence, but also prove that the present regulations for the medical relief of the poor require material changes before they can be made to approach anything like perfection; and, therefore, I trust they (the documents) will receive attention.

I have the honour to be, Sir, your obedient servant, Richard Griffin.

The Bight Hon. C. P. Villiers, Chairman Select Committee Poor Relief.

Poor-law Board, Whitehall, July 10th, 1863.

SrR, - I am desired by Mr. Villiers to inform you, that the Select Committee on Poor Relief have taken no evidence in the present session; and also to return to you the documents which you forwarded to him on the 22nd ult., as the Committee will not sit again during the session.

Richard Griffin, Esq I am, Sir, your obedient servant,

Hugh OweN.

CASE OF TRIPLETS.

To the Editor of THE LANCET.

SIR,-As triplets in midwifery do not fall to the lot of many practitioners, perhaps you may consider the undermentioned case, which has lately occurred in my practice, worth recording.

On the 1lth of April last, I was called up, about one o'clock in the morning, to go to the village of Bleadon, to attend in labour a poor woman of the name of Emma $\mathrm{C}$ - Bleadon is situated about two miles from my residence, so that when I arrived at my patient's house it was very nearly two o'clock. She had given birth to a male child, about five pounds and a half in weight, more than hour, when I reached her; but two women, who were staying with her, told me they believed there was another child behind, as the size of her abdomen did not seem much, if any, diminished. On placing my hand on her abdomen, I at once coincided with the women that there still must be another child to come. I of course made an ex amination per vaginam, and felt, very high up, the membranes containing another child beginning to protrude from the os uteri. At that time I could not, with any degree of cer tainty, say what the presentation was; neither could I do so till about four o'clock in the morning, by which time I very easily discovered the feet presenting. By five o'clock, with only a trifling interference on my part, a female child was born, which would have weighed about six pounds. The abdomen now had not very materially diminished in size, and still re. mained very hard, so that I was convinced the uterus, even yet, had in it a deal more of something than the placentæ. I again made an examination, and found a something beginning to protrude from the os uteri. In the space of half an hour it had sufficiently advanced to satisfy me that another child was making its way feet first. I very soon was enabled to seize the feet of this, the third, another male child, of about six pounds' weight; and as the external parts were well expanded, from the births of the two previons children, I had no difficulty whatever in bringing it into the world. The hardness of the abdomen had now much given way, but its size was still very great, occasioned, in part, from two placentæ, and in part from a rather unusual quantity of blood the uterus contained.

In a few minutes after the birth of the last child the woman became very faint, her pulse being scarcely to be felt, and fearful bæmorrhage came on. I, therefore, found that it would not do to delay matters, having satisfied myself that the pla centæ were still adherent. I at once introduced my hand into the uterus and remored the placentæ, and, as contraction of that organ did not immediately follow, I gave her a drachm of the liquor secalis cornuti (Curtis) in a little strong brandyand-water. This afforded her temporary relief only, for the hromorrhage continued, though in a less alarming degree, for an hour and a half from the time the last child was born. I gave her a second dose of the ergot, and continued the brandyand-water till such time as I considered it safe to discontinue it which was not till nearly three hours after the birth of the last child.

The woman's recovery has been protracted, on the whole, but I am now able to pronounce her (five weeks from the time of her confinement) well. The three children are all alive, and, as far as I am able to judge, likely to live.

It is as well I should remark, that the first child born-viz., that before I arrived,-from the statement of the women present, came into the world in the natural way. The protracted recovery of this woman cannot be much wondered at when two or three circumstances are taken into consideration. In the first place, her size, previous to confinement, was enormous; in the second place, her digestive organs had been much out of order for at least three months; and, in the third place, ber mind had been long impressed with an idea that at the time of her confinement she should die. This last and most distressing idea arose, $I$ think, in a great measure from her husband having been accidentally drowned about ten weeks before her confinement, whilst assisting in unloading a coal vessel.

I remain, Sir, your obedient servant,

Willitam Furnivale, M.R.C.S.

Hutton, near Weston-super-Mare, Somersetshire, 1863.

\section{THE BEDFORD MEDICO-ETHICAL SOCIETY AND HOMEOPATHY.}

To the Editor of THE Lances.

SIR,-As you have again done me the honour of introducing my name to the notice of your readers, I have to request that you will give the enclosed, together with this note, a place in your next issue. Making no use of "brass plates" myself, I must confess to a want of initiation into their mysteries. (I am aware, however, that they are composed of brass/) From this confession you will see that $I$ am quite unfit to hold office, or even to become a member of a society (ethical?) which does not scruple to use my name without either my knouledge or my consent?

Your obedient servant,
The Grove, Bedford, July, 1863.
G. Whartor.

Mill-street, June 20th, 1863.

Dear Sir,-Will you be good enough to see Mr. Graham, living opposite your house, this afternoon?

Whatever might have been said on a former occasion, I distinctly say that $I$ do not practise Homœopathy.

To Dr. Wharton.

I am, dear Sir, very truly yours,

JAMES CoOMBs.

\section{A R T I I C I A L L I M B S. To the Editor of THE LANCIE.}

Sir, - I have purposely refrained from making any reply to Mr. Masters' letter until I could ascertain from Dr. Robson the distinntion which exists between the artificial limb he has adopted and those ordinarily supplied; for, unless some new principle has been devised, I cannot see the reason for especially calling the attention of your readers to the subject in the manner which originally attracted my attention.

I feel assured you will agree with me that the mere modification of a general plan to suit the exigence of a special case cannot entitle any mechanician to the praise accorded to Mr. Masters, for if it did your columns would be filled with letters from those who had benefited by such a constant procedure.

On writing to Dr. Robson, and stating that the ordinary appliance consisted of a sheath for the stump, having an artificial foot attached to it by lateral ankle-joints, and usually, but not invariably, possessing in front an elastic band to represent the anterior muscles of the leg, and a cord behind fulfilling the function of the tendo-Achillis, he replied that, although he had never seen one of the legs I referred to, yet he conld not discover any difference between mine and his To quote his own words : "I have not seen one of the legs you refer to, but there does not seem much difference between mine and the one you refer to." He suggested that I should call upon Mr. 